Check for updates

Cite this: RSC Adv., 2019, 9, 2162

Received 6th December 2018 Accepted 8th January 2019

DOI: $10.1039 / c 8 r a 10048 a$

rsc.li/rsc-advances

\section{Temperature effect on extracellular polymeric substances (EPS) and phosphorus accumulating organisms (PAOs) for phosphorus release of anaerobic sludge $\uparrow$}

\begin{abstract}
Fanzhe Zeng, (DD a Wenbiao Jin ${ }^{\mathrm{b}}$ and Qingliang Zhao*a
Phosphorus $(\mathrm{P})$ is an essential element for living organisms and anaerobic sludge is an attractive source for $P$ recovery. Anaerobic $P$ release depends on both phosphorus-accumulating organisms (PAOs) and extracellular polymeric substances (EPS). However, the $P$ release contributed by the microbial cells and EPS was not addressed completely and the effect of temperature on the mechanism of $P$ release and transformation was rarely considered. This study, therefore, investigated the effects of temperature on the $\mathrm{P}$ fraction and the relationship between PAOs metabolic pathway and EPS reaction using the Standards in Measurements and Testing (SMT) protocol and the ${ }^{31} \mathrm{P}$ nuclear magnetic resonance ( ${ }^{31} \mathrm{P}-\mathrm{NMR}$ ) experiments. Experimental results showed that the temperature not only affected the metabolism of PAOs, but also significantly influenced the EPS components and the hydrolysis of EPS-associated polyphosphate (poly-P). And the $P$ release mainly occurred due to biological mechanisms with a conversion from non-reactive $P$ (NRP) in both intracellular and extracellular substances to reactive $P(R P)$ fractions. The highest concentration of total $P$ in the supernatant $\left(T_{L}\right)$ occurred at $15{ }^{\circ} \mathrm{C}$, and the $T P_{L}$ release from the solid to liquid phase was better fitted with pseudo-second-order kinetic model. More organic $P$ in the sludge $\left(O P_{s}\right)$ released from the sludge phase at $35{ }^{\circ} \mathrm{C}$ would convert into inorganic $P\left(I P_{s}\right)$ and non-apatite inorganic phosphorus $\left(N A I P_{s}\right)$ was the most labile $P$ fraction for $P$ release. The hydrolysis of EPS-associated poly- $P$ was enhanced by higher temperatures with the degradation of the long-chain poly-P by PAOs. Meanwhile, a lower temperature could obviously improve the $P$ release because the dominance of PAOs would potentially shift to GAOs with the increase of temperature. But the very-low temperature $\left(5^{\circ} \mathrm{C}\right)$ was not beneficial for the $P$ release and suppressed the microbial activities.
\end{abstract}

\section{Introduction}

Phosphorus (P) is an indispensable and non-renewable nutrient for agricultural fertilizers, but phosphate rocks will be exhausted in 100 years. ${ }^{1}$ Thus, $\mathrm{P}$ resource recovery is essential for a sustainable development of agriculture and society. The production of waste activated sludge (WAS) from wastewater treatment plants (WWTPs) increases rapidly with the development of urbanization and industrialization and meanwhile, is considered as a potential bioenergy source and hence can be used as a renewable energy production. ${ }^{2}$ More than $90 \% \mathrm{P}$ flowing into the wastewater is accumulated in the sewage sludge

${ }^{a}$ State Key Laboratory of Urban Water Resources and Environment (SKLUWRE), School of Environment, Harbin Institute of Technology, Harbin 150090, China. E-mail: qlzhao@hit.edu.cn; Tel: +86-45186283017

${ }^{b}$ School of Civil \& Environmental Engineering, Harbin Institute of Technology, Shenzhen 518055, China

$\dagger$ Electronic supplementary information (ESI) available. See DOI: 10.1039/c8ra10048a during wastewater treatments. Sewage sludge contains more than $12 \% \mathrm{P}$ of dry sludge by weight, ${ }^{3,4}$ and more than $40 \%$ of $\mathrm{P}$ exists in bounded biological biomass, while the rest is inorganic $\mathrm{P}$ of WAS. ${ }^{5,6}$ Thus, in order to use WAS as a $\mathrm{P}$ resource, the first step is to release $\mathrm{P}$ from WAS as more as possible for the following treatments of $\mathrm{P}$ recovery. According to sustainability policies and economic needs, the energy-efficient and environmentally friendly technology of phosphorus release from WAS is necessary and essential for WWTPs. Compared with chemical treatments, anaerobic phosphorus release from sewage sludge is verified as a sustainable and efficient $\mathrm{P}$ recovery method because of the avoidance of the eutrophication and algal bloom problems. $^{7}$

The fraction of phosphorus in the sludge is important as not all kinds of phosphorus fraction exhibit bio-availability. Therefore, the phosphorus fraction will be selected to evaluate the performance of the phosphorus release behavior rather than total phosphorus (TP) concentration. It was also reported that $40-60 \%$ of reactive $\mathrm{P}(\mathrm{RP})$ was existed in sewage sludge, 
which could be recoverable and available for chemical reactions. ${ }^{8}$ Non-reactive P (NRP) in the sludge phase should be firstly converted to soluble-RP (sRP), which could be recovered for direct use. It was known that RP was known as inorganic $\mathrm{P}$ (IP), orthophosphate (ortho-P), while NRP was known as organic P (OP) or polyphosphates. ${ }^{9}$ Standards in Measurements and Testing (SMT) protocol was used to investigate the distribution of phosphorus fractional phase in sludge samples. ${ }^{10}$ Thus, the NRP converted to RP fraction was contributed to the anaerobic $\mathrm{P}$ release and recovery.

In addition, anaerobic sludge is the pool of microorganisms for $\mathrm{P}$ release, which relies on a group of bacteria, i.e., phosphorus accumulating organisms (PAOs).${ }^{11}$ PAOs could store carbon sources as intracellular polymeric (poly- $\beta$-hydroxyalkanoate, PHA) and release ortho-P from the microbial cells using the energy of the degradation of glycogen and polyphosphate (poly-P). ${ }^{12-14}$ PAOs are identified as mesophiles or even psychrophiles. ${ }^{15}$ When the temperature is higher than $20{ }^{\circ} \mathrm{C}$, PAOs and glycogen accumulating organisms (GAOs) will compete for the carbon source uptake. In such a case, GAOs waste the energy, but no polyphosphate will be accumulated for the $\mathrm{P}$ recovery. ${ }^{16}$ Moreover, the activity of the phosphatase, which is a kind of hydrolytic enzyme for the $\mathrm{P}$ release from organic phosphorus in the sludge, is influenced by the temperature. Therefore, temperature is a key parameter because it affects the microbial population characteristics and the metabolic activity of anaerobic sludge. However, most of the studies focused on the effect of $\mathrm{pH}$ on $\mathrm{P}$ release of different $\mathrm{P}$ fractions, and very few studies were conducted to investigate and identify the effects of temperature on the $\mathrm{P}$ fractions and $\mathrm{P}$ release. ${ }^{17}$ In this study, a moderate temperature was selected because high temperatures would consume more energy and lead to the lower process stability, especially for the operation of WWTPs in cold regions. ${ }^{18}$ Moreover, it was reported that temperature higher than $20{ }^{\circ} \mathrm{C}$ was unfavorable for biological phosphorus removal. ${ }^{19}$ In such a case, a reasonable wider temperature range, $5-35{ }^{\circ} \mathrm{C}$, was considered and investigated for anaerobic treatments in this study. Thus, the lowtemperature thermal treatment for phosphorus release was regarded as a low energy process, which led to a biodegradability enhancement and a simultaneous release of $\mathrm{P}$ from anaerobic sludge.

In addition to the microbial cells, extracellular polymeric substances (EPS), which store a large amount of phosphorus, is the other important factor in the anaerobic phosphorus release process. $^{20,21}$ EPS is composed of organic compounds such as proteins, carbohydrates, humic acid and phospholipid, which could protect microbial cells and combine with inorganic ions like Ca or Mg. In fact, $27-30 \%$ of total P (TP) was contained in EPS in activated sludge. ${ }^{22,23}$ Meanwhile, EPS influenced the transformation of P between bulk solution and PAOs because the sludge flocs were crabbed with EPS matrix and their transformation should be passed through. EPS had great influence on microbial aggregates because of its special characteristics due to its components of EPS, such as polysaccharide, proteins. ${ }^{24}$ The main phosphorus fractions in EPS were identified as the coexistence of ortho-P, poly-P using ${ }^{31} \mathrm{P}$ nuclear magnetic resonance (NMR) technology. ${ }^{25,26}$ The phosphorus release of EPS was obviously influenced by many factors, such as organic loading, influent metal concentration and $\mathrm{pH}^{27,28}$ But few studies were conducted to validate the influence of temperature on the P release and P fractions of EPS.

Although the temperature affected the distribution of phosphorus fractions because of their different removal mechanisms and transformation, the effects of temperature on the characteristics and function of phosphorus fractions in intracellular cells and EPS needed to be further investigated. ${ }^{29}$ Thus, it was essential to find out the optimum temperature for EPS production and degradation as well as optimum for $\mathrm{P}$ release by groups of bacteria. Facing the aforementioned problems, this study, therefore, explored that how the temperature affected the migration and transformation of phosphorus among microbial cells, EPS and liquid phase using ${ }^{31} \mathrm{P}-\mathrm{NMR}$ method. The main contributions of this study include (1) to study the effect of temperature on the relationship between phosphorus fractions and anaerobic P release; (2) to investigate the roles of EPS played in the anaerobic NRP fraction to RP fraction conversion process; (3) to identify the optimal temperature for the $\mathrm{P}$ release in both intracellular and extracellular phases.

\section{Materials and methods}

\subsection{Phosphorus release test of anaerobic sludge}

The WAS in this study was obtained from the secondary sedimentation tank of a WWTP with an anaerobic/anoxic/aerobic $\left(\mathrm{A}^{2} / \mathrm{O}\right)$ process located in Shenzhen, China. The WAS sample was firstly thickened for $24 \mathrm{~h}$ at $4{ }^{\circ} \mathrm{C}$ by gravitational sedimentation (97\% moisture content after thickening), and then screened with a $1 \mathrm{~mm}$ sieve and finally stored at $4{ }^{\circ} \mathrm{C}$ for the following tests. The main characteristics of activated sludge were as follows: $\mathrm{pH}$ 6.6; total suspended solids (TSS) $18.95 \mathrm{~g} \mathrm{~L}^{-1}$, volatile suspended solids (VSS)/TSS ratio of 0.64 ; soluble chemical oxygen demand (SCOD) $260.5 \mathrm{mg} \mathrm{L}^{-1}$; ammonia nitrogen $\left(\mathrm{NH}_{4}{ }^{+}-\mathrm{N}\right) 72.5 \mathrm{mg} \mathrm{L}^{-1}$; ortho-P concentration $\left(\mathrm{PO}_{4}{ }^{3-}-\mathrm{P}\right)$ $38.9 \mathrm{mg} \mathrm{L}^{-1}$; soluble Ca $32 \mathrm{mg} \mathrm{L}^{-1}$; and soluble $\mathrm{Mg} 24 \mathrm{mg} \mathrm{L}^{-1}$.

In the anaerobic phosphorus release batch laboratory-scale tests, $300 \mathrm{~mL}$ sludge samples were placed into $500 \mathrm{~mL}$ capped and sealed beakers, which were incubated in a temperaturecontrolling shaking water-bath (SHZ-B, Xinrui, China) at 5, 15, $25,35{ }^{\circ} \mathrm{C}$ for $200 \mathrm{~min}$ (note that the test duration was set as 200 min because the $\mathrm{P}$ release kinetic tests could reach their equilibria within $200 \mathrm{~min}$, which was also validated by $\mathrm{Xu}$ et al.). ${ }^{3}$ Sodium acetate $\left(6.25 \mathrm{mmol} \mathrm{L}^{-1}\right)$ was added as the sole carbon source for enhancing the anaerobic phosphorus release. The $\mathrm{pH}$ was controlled at 7.0 by adding $1 \mathrm{M} \mathrm{HCl}$ or $\mathrm{NaOH}$. The mixed solution $(30 \mathrm{~mL})$ was taken out every $20 \mathrm{~min}$ for the extraction of phosphorus in sludge $(10 \mathrm{~mL})$ and the extraction of EPS $(20 \mathrm{~mL})$. The supernatant was measured for the analysis of TP concentration in the bulk solution $\left(\mathrm{TP}_{\mathrm{L}}\right)$, while the sludge samples were dried at $105{ }^{\circ} \mathrm{C}$ for $24 \mathrm{~h}$. The powdered sludge samples were sieved by passing through 100 mesh sieves to analyze the $\mathrm{P}$ fraction in the solid phase. 


\subsection{Phosphorus fractions in sludge samples}

The total phosphorus in sludge $\left(\mathrm{TP}_{\mathrm{S}}\right)$ was divided into four fractions according to the SMT protocol: organic $\mathrm{P}\left(\mathrm{OP}_{\mathrm{s}}\right)$, inorganic $\mathrm{P}\left(\mathrm{IP}_{\mathrm{s}}\right)$, apatite inorganic phosphorus $\left(\mathrm{AP}_{\mathrm{s}}\right.$, the $\mathrm{P}$ species associated with $\mathrm{Ca}$ ) and non-apatite inorganic phosphorus $\left(\mathrm{NAIP}_{\mathrm{s}}\right.$, the $\mathrm{P}$ species associated with oxides and hydroxides of $\mathrm{Al}, \mathrm{Fe}, \mathrm{Mg}$ and $\mathrm{Mn}$ ), in order to investigate the characteristics and behaviors of phosphorus release. In brief, sludge samples were firstly dried for $48 \mathrm{~h}$ and the powdered sludge samples were used for subsequent fractionation. $\mathrm{TP}_{\mathrm{s}}$ was determined by processing the sludge sample at $450{ }^{\circ} \mathrm{C}$ for $3 \mathrm{~h}$ following by $\mathrm{HCl}$ extraction $(3.5 \mathrm{M})$. $\mathrm{IP}_{\mathrm{s}}$ was extracted by $\mathrm{HCl}(1 \mathrm{M})$, and the residue $\left(\mathrm{OP}_{\mathrm{s}}\right)$ was treated at $450{ }^{\circ} \mathrm{C}$ for $3 \mathrm{~h}$ by $\mathrm{HCl}$ extraction $(1 \mathrm{M})$. NAIP $_{\mathrm{s}}$ was firstly extracted by $\mathrm{NaOH}(1 \mathrm{M})$ and the supernatant was then extracted by $\mathrm{HCl}(3.5 \mathrm{M})$, while $\mathrm{AP}_{\mathrm{s}}$ was extracted by $\mathrm{HCl}(1 \mathrm{M})$. The samples were frozen immediately at $-80{ }^{\circ} \mathrm{C}$, lyophilized at $-20{ }^{\circ} \mathrm{C}$ until analysis. Every process needed to follow by stirring for $16 \mathrm{~h}$ at room temperature. The phosphorus concentration in the supernatant after extraction processes was measured by the molybdenum blue method as described in Standard Methods. ${ }^{9}$ The detailed extraction processes were followed by the precious publications. ${ }^{\mathbf{8} 26}$

\subsection{Extraction of EPS and collection of microbial cells}

Formaldehyde/NaOH (0.06 mL, 36.5\% formaldehyde/4 mL, $1 \mathrm{M}$ $\mathrm{NaOH}$ ) was used to extract EPS matrix from sludge samples at $4{ }^{\circ} \mathrm{C}$ according to Liu et al., which was with a high phosphorus extraction efficiency but without the damage of microbial cells. ${ }^{30}$ The EPS extraction was freeze-dried for $48 \mathrm{~h}$ at $-50{ }^{\circ} \mathrm{C}$ for the subsequent ${ }^{31} \mathrm{P}-\mathrm{NMR}$ analysis.

The centrifugal precipitation (through the $0.2 \mu \mathrm{m}$ membrane) was regarded as the microbial cell. $0.4 \mathrm{~mL}$ of $100 \mathrm{mmol} \mathrm{L}^{-1}$ EDTA solution, $0.6 \mathrm{~g}$ of $0.1 \mathrm{~mm}$ quartz-sand and 3 steel balls were added into the freeze-dried microbial cells. Then, the intracellular phosphorus was largely released from microbial cell samples using the automatic grinding instrument (Tissuelyser-FEII, Jingxin, China) and centrifuged twice at $0 \pm 2{ }^{\circ} \mathrm{C}$ for $20 \mathrm{~min}$. The centrifugal supernatant was used for total phosphorus concentration analysis and ${ }^{31} \mathrm{P}-\mathrm{NMR}$ analysis.

\section{$2.4{ }^{31}$ P-NMR analysis}

The freeze-dried EPS extraction (15 mg) was dissolved with $0.4 \mathrm{~mL}$ of $\mathrm{D}_{2} \mathrm{O}$ and $0.2 \mathrm{~mL}$ of $100 \mathrm{mmol} \mathrm{L}^{-1}$ EDTA solution. And the microbial cell centrifugal supernatant $(0.2 \mathrm{~mL})$ added with $0.4 \mathrm{~mL}$ of $\mathrm{D}_{2} \mathrm{O}$ was prepared for the following ${ }^{31} \mathrm{P}-\mathrm{NMR}$ analysis using an NMR spectrometer (Bruker Avance-600 MHz., Germany) at $162 \mathrm{MHz}$ for ${ }^{31} \mathrm{P}^{31}$ Before analysis, $0.2 \mathrm{~mL}$ of $2 \mathrm{~mol} \mathrm{~L}^{-1}$ $\mathrm{NaOH}$ needed to be dissolved in $\mathrm{D}_{2} \mathrm{O}$. The acquisition parameters were as follows: acquisition time, $0.51 \mathrm{~s}$; relaxation delay, $50 \mathrm{~s} ; 90^{\circ}$ pulse width, $9.6 \mu \mathrm{s}$ and an external $85 \% \mathrm{H}_{3} \mathrm{PO}_{4}$ standard $(\delta=0)$. The spectra were analyzed according to a previous study and the data were determined by NMR data processing software (MestReNova v6.1.0-6224). ${ }^{32}$

\subsection{Kinetic modeling of TP accumulation in bulk solution}

Kinetic models (pseudo-first-order, PFO; pseudo-secondorder, PSO) were built to describe the process of phosphorus releasing into the bulk solution. The PFO and PSO models were determined by eqn (1) and (2) and eqn (3) and (4), respectively. ${ }^{33}$

$$
\begin{gathered}
\frac{\mathrm{d} q_{t}}{\mathrm{~d} t}=k_{1}\left(q_{\mathrm{e}}-q_{t}\right) \\
\ln \left(q_{\mathrm{e}}-q_{t}\right)=\ln q_{\mathrm{e}}-k_{1} t \\
\frac{\mathrm{d} q_{t}}{\mathrm{~d} t}=k_{2}\left(q_{\mathrm{e}}-q_{t}\right)^{2} \\
\frac{t}{q_{t}}=\frac{1}{k_{2} q_{\mathrm{e}}^{2}}+\frac{t}{q_{\mathrm{e}}}
\end{gathered}
$$

where, $k_{1}$ is the rate constant of $\mathrm{PFO}, \min ^{-1}, k_{2}$ is the rate constant of PSO, L (mg min $)^{-1}, q_{t}\left(\mathrm{mg} \mathrm{L}^{-1}\right)$ is the concentration of $\mathrm{TP}_{\mathrm{L}}$ at time $t$ (min), $q_{\mathrm{e}}$ is the equilibrium $\mathrm{TP}$ concentration, $\mathrm{mg} \mathrm{L}^{-1}$. The correlation coefficient $\left(R^{2}\right)$, normalized standard deviation $(\Delta q(\%))$ and average relative error (ARE (\%)) were used to evaluate the accuracy of these two models, which were determined by eqn (5) and (6): ${ }^{34}$

$$
\begin{gathered}
\Delta q(\%)=100 \sqrt{\frac{1}{N-1} \sum_{i=1}^{N}\left(\frac{q_{t, \text { exp }}-q_{t, \mathrm{cal}}}{q_{t, \mathrm{exp}}}\right)_{i}^{2}} \\
\operatorname{ARE}(\%)=\frac{100}{N-1} \sum_{i=1}^{N}\left(\frac{q_{t, \exp }-q_{t, \mathrm{cal}}}{q_{t, \exp }}\right)_{i}^{2}
\end{gathered}
$$

where, $N$ is the measurements number, $q_{\mathrm{e}, \mathrm{cal}}$ is the calculated value and $q_{\mathrm{e}, \exp }$ is the experimental value, $\mathrm{mg} \mathrm{L}^{-1}$.

\subsection{Other analytical methods}

The sludge samples were taken out and immediately centrifuged at $3000 \mathrm{rpm}$ for $10 \mathrm{~min}$ (TDL-80-2C, Anting, China) with the total phosphorus (TP) content in the supernatant phase being measured. The TP concentrations in bulk solution $\left(\mathrm{TP}_{\mathrm{L}}\right)$, EPS $\left(\mathrm{TP}_{\mathrm{EPS}}\right)$ and microbial cell $\left(\mathrm{TP}_{\text {cell }}\right)$ were measured using spectrophotometer (T6, Beijing Purkinje General Instrument, Beijing, China) according to the molybdenum blue method in Standard Methods. ${ }^{9}$ Total suspended solids (TSS) and volatile suspended solids (VSS) were analyzed according to the standard method. The acetate concentration was measured by a gas chromatography (7980A, Agilent Technologies, USA) equipped with a flame ionization detector. The measurements of glycogen, PHA intracellular polymers (poly- $\beta$-hydroxybutyrate (PHB) and polyhydroxyvalerate (PHV)) and acetate in the anaerobic sludge were performed according to Wang et al. ${ }^{35}$ Extracellular proteins in EPS phase were determined with the Lowry method and extracellular polysaccharides were measured by the phenol-sulfuric acid method. ${ }^{36,37}$ 


\section{Results and discussion}

3.1 Phosphorus concentration and distribution in anaerobic sludge at different temperatures

At different temperatures, the TP concentration and distribution during the anaerobic treatments were shown in Fig. 1. The concentration of $\mathrm{TP}_{\mathrm{L}}$ rapidly increased with a decrease of $\mathrm{TP}_{\mathrm{S}}$ concentration, indicating that phosphorus in the sludge phase was released into the bulk solution during the anaerobic treatment. The highest $\mathrm{TP}_{\mathrm{L}}$ concentration reached $190.2 \mathrm{mg} \mathrm{L}^{-1}$ at $15{ }^{\circ} \mathrm{C}$, while, at other temperatures, the sludge exhibited a relatively lower $\mathrm{P}$ release ability. The changes of $\mathrm{TP}_{\mathrm{L}}$ concentration at different temperatures were mainly caused by two reasons: the potential release of sludge and the hydrolysis of EPS-associated phosphorus.

The TP contents of anaerobic sludge released phosphorus at $5{ }^{\circ} \mathrm{C}, 15{ }^{\circ} \mathrm{C}, 25{ }^{\circ} \mathrm{C}$ and $35{ }^{\circ} \mathrm{C}$ were $12.85 \mathrm{mg} \mathrm{g}_{\text {vss }}{ }^{-1}, 18.97 \mathrm{mg}$ $\mathrm{g}_{\text {vss }}{ }^{-1}, 15.56 \mathrm{mg} \mathrm{g}_{\mathrm{vss}}{ }^{-1}$ and $14.86 \mathrm{mg}_{\mathrm{vss}}{ }^{-1}$, respectively. The content of $\mathrm{TP}_{\text {cell }}$ showed a similar trend with $\mathrm{TP}_{\mathrm{s}}$ concentration, and the extremely low temperature $\left(5^{\circ} \mathrm{C}\right)$ may be harmful to the activities of PAO cells in storing $\mathrm{P}$ as intracellular poly-P. The content of $\mathrm{TP}_{\text {cell }}$ kept almost constant at first $20 \mathrm{~min}$ for adapting to the harsh environment and then decreased rapidly at $5{ }^{\circ} \mathrm{C}$. EPS was mainly comprised of protein and polysaccharide. As shown in Fig. 2, temperature also obviously affected the EPS components, especially the polysaccharide content that was increased by a low temperature. Liu et al. similarly concluded that the polysaccharides content of EPS at $5{ }^{\circ} \mathrm{C}$ was two-fold higher than those at 15 and $25{ }^{\circ} \mathrm{C} .{ }^{38}$ The increase of polysaccharide content improved the adsorption ability of EPS and hence the $\mathrm{P}$ accumulating as well as microbial

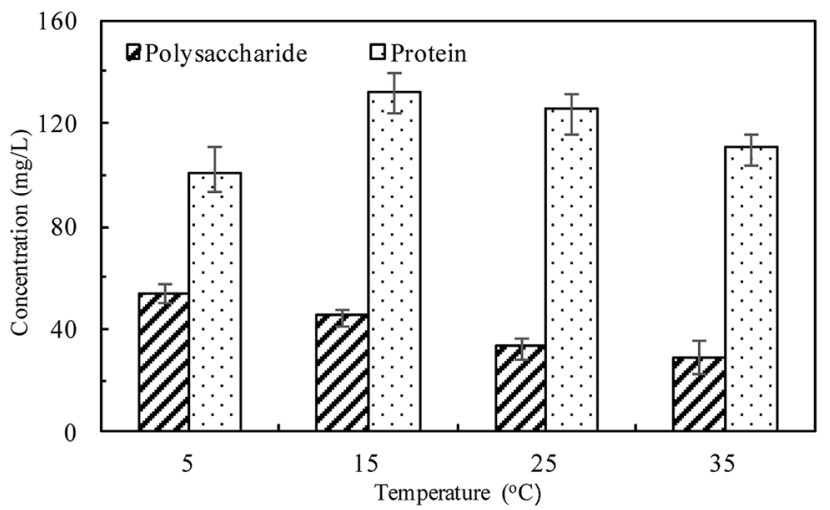

Fig. 2 Changes of EPS components in anaerobic sludge at different temperatures.

aggregation in the EPS phase. ${ }^{39}$ EPS showed a stronger hydrophilicity at a lower temperature. Due to the protection of protein tightly packed around the sludge flocs, some metal ions could be precipitated with $\mathrm{P}$ entrapped in the EPS matrix and affected the $\mathrm{P}$ release. ${ }^{40}$ After 200 min-anaerobic phosphorus releasing process, $2.21 \mathrm{mg}_{\mathrm{vss}}{ }^{-1}$ of $\mathrm{TP}_{\mathrm{EPS}}$ was released at $35^{\circ} \mathrm{C}$, but only $0.17 \mathrm{mg} \mathrm{g}_{\mathrm{VSS}}{ }^{-1}$ and $0.75 \mathrm{mg} \mathrm{g}_{\mathrm{VSs}}{ }^{-1}$ of $\mathrm{TP}_{\mathrm{EPS}}$ were absorbed by EPS at $15{ }^{\circ} \mathrm{C}$ and $25{ }^{\circ} \mathrm{C}$, respectively. In addition, $2.18 \mathrm{mg} \mathrm{g}_{\mathrm{vss}}{ }^{-1}$ of phosphorus was accumulated in the EPS at $5{ }^{\circ} \mathrm{C}$, which demonstrated that a higher content of polysaccharide in EPS enhanced the $\mathrm{P}$ accumulation in EPS. Notably, the $\mathrm{TP}_{\mathrm{EPS}}$ content approached balance in the later period of the anaerobic process at $5{ }^{\circ} \mathrm{C}$ (Fig. 1), but a continuous decline occurred at other temperature tests. This may be because the extremely low temperature was not beneficial for the $\mathrm{P}$ transformation from

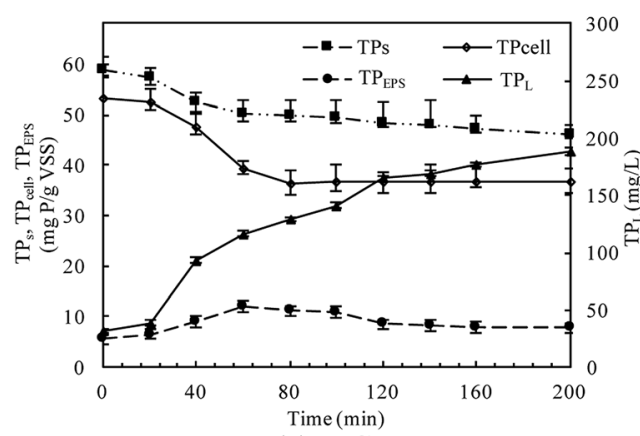

(a) $5^{\circ} \mathrm{C}$

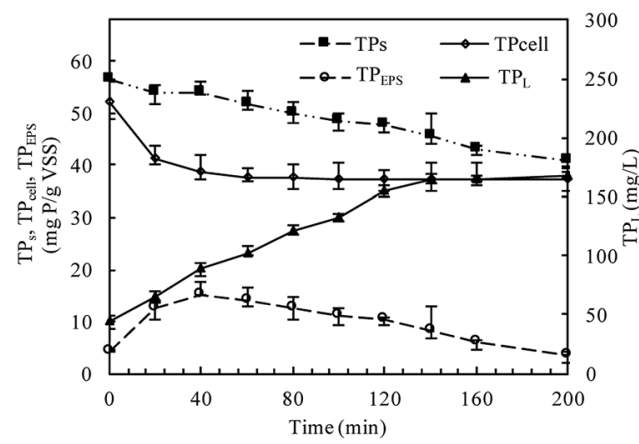

(c) $25^{\circ} \mathrm{C}$

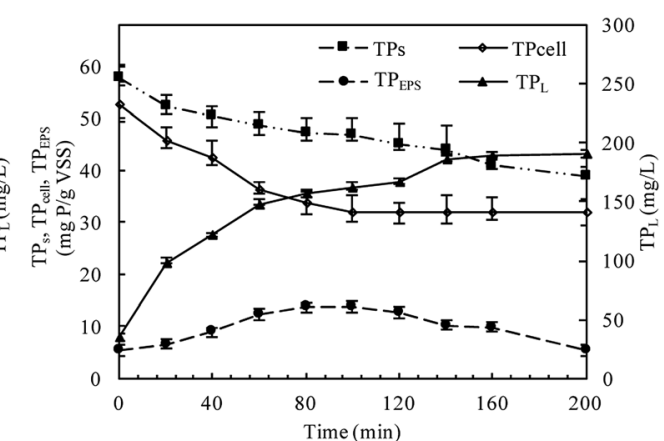

(b) $15^{\circ} \mathrm{C}$

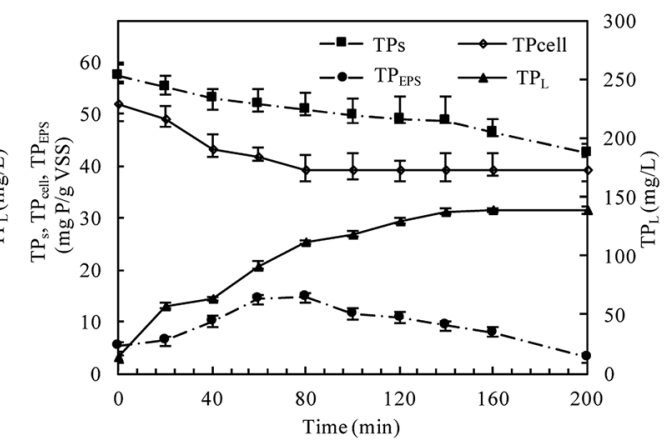

(d) $35^{\circ} \mathrm{C}$

Fig. 1 Changes of TP concentration and distribution in anaerobic sludge at different temperatures. 


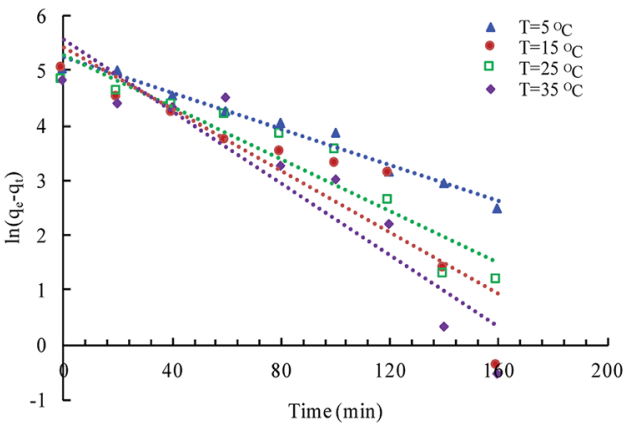

(a)

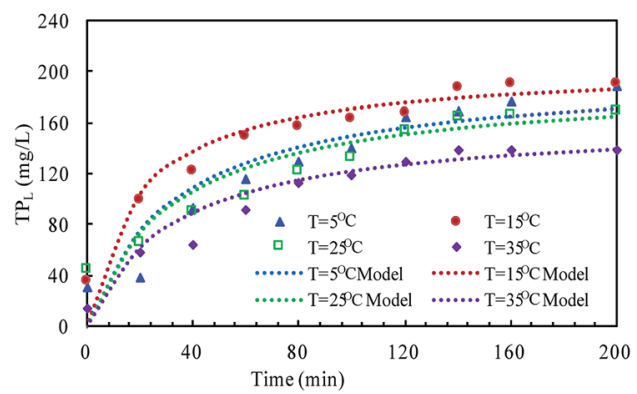

(c)

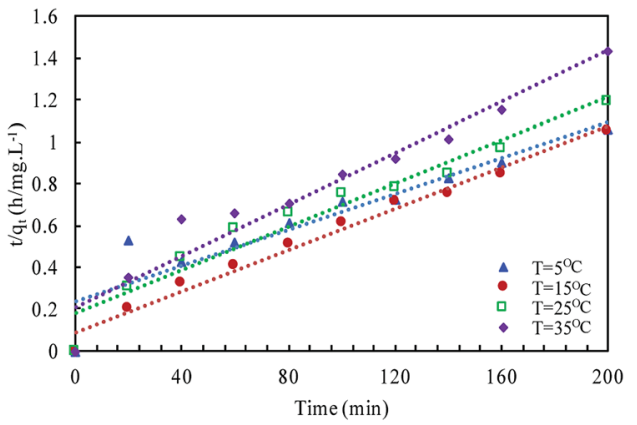

(b)

Fig. 3 Kinetic modeling of TPL release in the liquid phase at different temperatures (a) fitting line of pseudo-first-order; (b) fitting line of pseudosecond-order; (c) match curves between measured and modeled values in pseudo-second-order model.

microbial cells and the hydrolysis of EPS slowed down caused by few exopolyphosphatases in EPS. At $35^{\circ} \mathrm{C}, \mathrm{TP}_{\mathrm{EPS}}$ gradually increased from $5.18 \mathrm{mg} \mathrm{g}_{\mathrm{vss}}{ }^{-1}$ to $14.67 \mathrm{mg} \mathrm{g}_{\mathrm{vss}}{ }^{-1}$ at $60 \mathrm{~min}$, which showed an obvious $\mathrm{P}$ accumulation. ${ }^{41}$ Then, $\mathrm{TP}_{\mathrm{EPS}}$ significantly decreased to $2.97 \mathrm{mg} \mathrm{g}_{\mathrm{Vss}}{ }^{-1}$ because of the EPS hydrolysis, which could reduce macromolecules and particulate matter into the metabolizable low-molecular-weight P. Thus, the contribution of extracellular $\mathrm{P}$ release could not be neglected.

The linear expressions of the two models were presented in Fig. 3 and the parameters were presented in Table 1. The kinetic models were used to understand the phosphorus release to the bulk solution. According to the $R^{2}$ values, the identified PSO model was better than PFO model for phosphorus accumulation in the bulk solution. The model parameter $k_{2}$ was highest at $15{ }^{\circ} \mathrm{C}$ with the largest amount of $q_{\mathrm{e}}\left(204.08 \mathrm{mg} \mathrm{L}^{-1}\right)$, indicating that $15{ }^{\circ} \mathrm{C}$ was the possible best temperature for the anaerobic phosphorus release. And the initial release rates expressed as $k_{2} q_{\mathrm{e}}{ }^{2}$, were $6.002,10.412,5.917$ and $4.94 \mathrm{mg}(\mathrm{L} \mathrm{min})^{-1}$ along with the temperature increased from $5{ }^{\circ} \mathrm{C}$ to $35{ }^{\circ} \mathrm{C}$. Thus, the phosphorus release from the solid to liquid phase was influenced by the pseudo-second-order reaction at different temperatures and the low temperature (especially $15{ }^{\circ} \mathrm{C}$ ) was preferable for $\mathrm{P}$ release into the bulk solution.

\subsection{Phosphorus fractions of anaerobic sludge by SMT protocol}

The changes of phosphorus fractions and distribution in the sludge phase at different temperatures were shown in Fig. 4. $\mathrm{P}$ mass stored in the residue sludge could be used as an indicator to assess the $\mathrm{P}$ release ability of PAOs. The $\mathrm{P}$ release amount was obviously affected by the temperature, with $\mathrm{TP}_{\mathrm{s}}$ release percentages of $21.8 \%, 32.8 \%, 27.6 \%$ and $25.9 \%$ with the temperature of $5{ }^{\circ} \mathrm{C}, 15{ }^{\circ} \mathrm{C}, 25{ }^{\circ} \mathrm{C}$, and $35{ }^{\circ} \mathrm{C}$, respectively. The $\mathrm{TP}_{\mathrm{s}}$ was the sum of $\mathrm{IP}_{\mathrm{s}}$ and $\mathrm{OP}_{\mathrm{s}}$, and its content decreased to a minimum value of $31.58 \mathrm{mg} \mathrm{g}_{\mathrm{vss}}{ }^{-1}$ at $15{ }^{\circ} \mathrm{C}$. The consistent result was obtained with that presented in the above session (Section 3.1).

$\mathrm{IP}_{\mathrm{s}}$ was the major $\mathrm{P}$ fraction of anaerobic sludge and mainly dominated $\mathrm{P}$ dynamics due to the high content of the labile $\mathrm{P}$

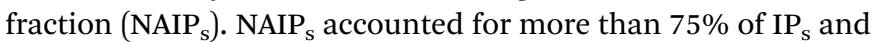
the percentage of NAIP $_{S}$ kept constant with the increase in temperature. The release efficiencies of $\mathrm{IP}_{\mathrm{s}}$ were related to the changes of $\mathrm{NAIP}_{\mathrm{s}}$ and $\mathrm{AP}_{\mathrm{s}}$. The $\mathrm{NAIP}_{\mathrm{s}}$ was considered as the most labile phosphorus fraction and its release would be enhanced by the increase of temperature. The content of $\mathrm{AP}_{\mathrm{S}}$ was almost unchanged at all temperatures indicating that $\mathrm{AP}_{\mathrm{s}}$ was much more stable than $\mathrm{NAIP}_{\mathrm{s}}$. At $35^{\circ} \mathrm{C}$, the ratio of $\mathrm{AP}_{\mathrm{s}} / \mathrm{IP}_{\mathrm{s}}$ increased obviously with a relative decrease of $\mathrm{NAIP}_{\mathrm{S}} / \mathrm{IP}_{\mathrm{s}}$, indicating that a higher temperature could effectively improve the $\mathrm{P}$ bioavailability resulting from the conversion of $\mathrm{NAIP}_{\mathrm{s}}$ to $\mathrm{AP}_{\mathrm{s}}$.

Moreover, the proportion of $\mathrm{OP}_{\mathrm{s}}$, named as one of the main compounds of NRP in $\mathrm{TP}_{\mathrm{s}}$, was relatively stable in the all temperatures conditions. But the release rate of $\mathrm{OP}_{\mathrm{s}}$ at higher temperature was much quicker than that at low temperatures, indicating that a higher temperature could accelerate the release of $\mathrm{OP}_{\mathrm{s}}$ with the dissolution of $\mathrm{IP}_{\mathrm{s}}$ combined with metal ions in the sludge phase. The content of $\mathrm{OP}_{\mathrm{s}}$ was almost unchanged at the first $40 \mathrm{~min}$ of the anaerobic process, and then significantly decreased. The release content of $\mathrm{OP}_{\mathrm{s}}$ reached the maximum value of $7.04 \mathrm{mg} \mathrm{g}_{\mathrm{vss}}{ }^{-1}$ at $35{ }^{\circ} \mathrm{C}$, while only 
Table 1 Kinetic parameters of two models at different temperatures

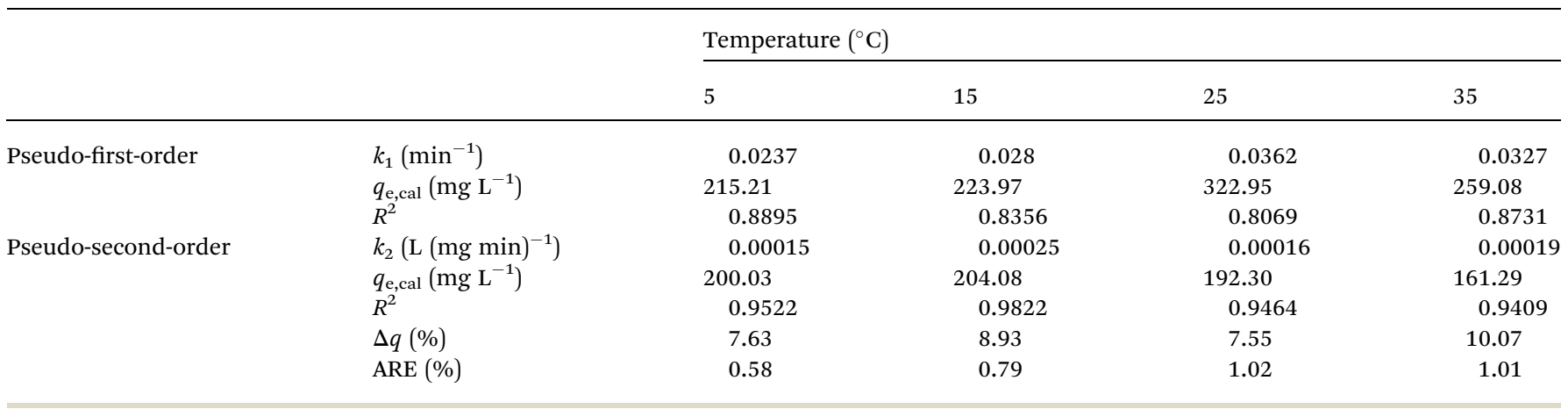

$2.63 \mathrm{mg} \mathrm{g} \mathrm{vss}^{-1}$ of $\mathrm{OP}_{\mathrm{s}}$ was released at $5{ }^{\circ} \mathrm{C}$. At $35{ }^{\circ} \mathrm{C}, \mathrm{P}$ amount stored in the biomass decreased by $80.73 \%$ of $\mathrm{OP}_{\mathrm{s}}$ after $200 \mathrm{~min}$ anaerobic process, but the $\mathrm{OP}_{\mathrm{s}}$ release was tended to be stable due to the inhibition of PAOs activity. The release of $\mathrm{OP}_{\mathrm{s}}$ increased with temperature increasing due to both the sludge disintegration and microbial metabolism.

Thus, different $\mathrm{P}$ fractions and compositions behave differently as $\mathrm{IP}_{\mathrm{s}}$ could be easier to release, while $\mathrm{OP}_{\mathrm{s}}$ commonly passed through. The sum of $\mathrm{NAIP}_{\mathrm{s}}$ and $\mathrm{OP}_{\mathrm{s}}$ was regarded as potential bio-available phosphorus for the following phosphorus release. ${ }^{42}$ The percentage of $\mathrm{NAIP}_{\mathrm{s}}$ and $\mathrm{OP}_{\mathrm{s}}$ in this study was about 78.01-82.24\%, and the ratio of potential bio-available phosphorus to $\mathrm{TP}_{\mathrm{s}}$ kept almost constant during the anaerobic process, thus, it showed a high potentially bio-available phosphorus stored in the anaerobic sludge.

\subsection{Phosphorus fractions of EPS}

Because anaerobic processes at lower temperatures destroyed the polymeric structure of EPS and strengthened the attached components of microbial cells, macromolecular polyphosphates released from microbial cells could not release into the supernatant directly. Phosphorus released from microbial cells firstly leaked into the EPS and then desorbed the most of EPS-associated $\mathrm{P}$ into the bulk solution.

The ${ }^{31} \mathrm{P}-\mathrm{NMR}$ spectroscopies of EPS at different temperatures were shown in Fig. 5, and the chemical shifts and relative percentage of identified phosphorus fractions were presented in Table $\mathrm{S} 1 . \dagger$ Five $\mathrm{P}$ species, i.e., ortho-P, poly- $\mathrm{P}$, orthophosphate monoesters (monoester-P), orthophosphate diesters (diester-P) and pyrophosphate (pyro-P), were identified in EPS from their signals at $5.48,-4.37$ for end groups of poly-P, -18.89 for middle groups of poly-P, 3.78-4.16, -2.05 and $-5.01 \mathrm{ppm}$, respectively. The ${ }^{31} \mathrm{P}-\mathrm{NMR}$ spectroscopy showed that poly-P and ortho-P were the dominant forms of $\mathrm{P}$ in EPS. The signals of organic phosphorus fractions (monoester-P and diester-P) were observed at $5{ }^{\circ} \mathrm{C}$ but the signals of organic $\mathrm{P}$ almost disappeared and those of inorganic $\mathrm{P}$ remained at other temperatures. The monoester-P and diester-P, related to the activity and concentration of living cells, were released with the disintegration of sludge and then transformed to inorganic phosphorus. Such complex $\mathrm{P}$ components in the EPS at $5{ }^{\circ} \mathrm{C}$ revealed that the activity of degrading enzymes (exopolyphosphatases) in the hydrolysis of EPS was weakened at a low temperature. This observation was similar with the release trend in the anaerobic sludge (Fig. 4), and a higher temperature was beneficial to transform the $\mathrm{OP}_{\mathrm{s}}$ to $\mathrm{IP}_{\mathrm{s}}$ (especially $\mathrm{NAIP}_{\mathrm{s}}$ ), which led to a conversion to the RP fraction.

The poly-P in the raw sludge phase was long-chain (about 42) by ${ }^{31} \mathrm{P}$-NMR spectra, which was reduced during the anaerobic treatment. The similar result was reported by Lichko et al. ${ }^{\mathbf{4 3}}$ The mean chain length of poly-P was calculated as eqn (7). The chain length of poly-P at moderate temperatures was much shorter than that at a lower temperature. This indicated that the hydrolysis of EPS-associated poly-P was enhanced by higher temperatures with the degradation of the long-chain poly-P. The long-chain poly-P intercepted by EPS was further degraded to short-chain poly-P and pyro-P by PAOs. These short-chain poly-P and pyro-P were then degraded to ortho-P and released into the liquid. As the amounts of EPS increased at lower temperatures, more macromolecular phosphorus was accumulated in EPS. Lower temperatures led to a much stronger affinity with multichain phosphorus. But the extracellular enzyme was not enough to provide the energy for the hydrolysis of EPS in a very lowtemperature condition $\left(5{ }^{\circ} \mathrm{C}\right)$. Thus, the proportion of poly-P was much higher than those at other temperatures (reflected by higher peak contents). The degradation of high molecular weight poly-P and pyro-P associated with polymeric materials could provide the energy for the P release process.

$$
\begin{gathered}
\text { Poly-P mean chain length }=2+2 \text { (middle groups of } \\
\text { poly-P/end groups of poly-P) }
\end{gathered}
$$

Similarly, ortho-P was easily found in nucleic acids or hydroxide groups in polysaccharide of EPS, because the content of polysaccharide in EPS was significantly increased at the lower temperature. ${ }^{44}$ Ortho-P existed in EPS was related to two sources, i.e., intracellular poly-P directly leaked into the extracellular polymeric matrix and extracellular poly-P phase degraded to ortho-P by degrading enzymes.

The binding between EPS-associated $\mathrm{P}$ (negative charges) and metal ions, such as $\mathrm{Ca}^{2+}, \mathrm{Mg}^{2+}$ was enhanced by lower temperatures, which was the main nutrient for living organisms. ${ }^{25}$ These two-divalent cation-P compounds named as particular reactive $\mathrm{P}$ (pRP) were presented in the EPS matrix. Such intermolecular interactions were the basis of maintaining the microbial aggregate structure with a higher proportion of ortho-P (soluble RP, sRP) in EPS. ${ }^{8}$ And extracellular ortho-P and 


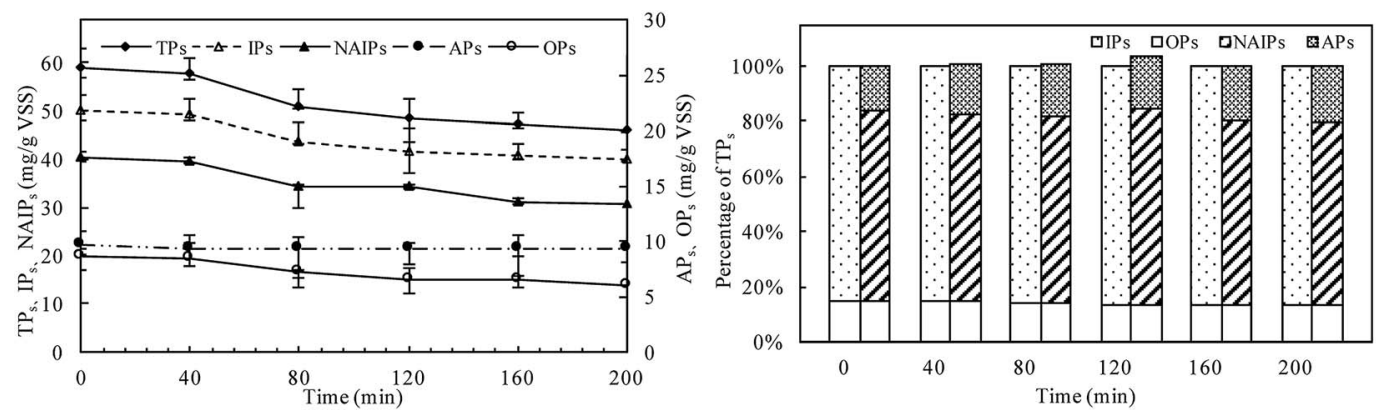

(a) $5^{\circ} \mathrm{C}$

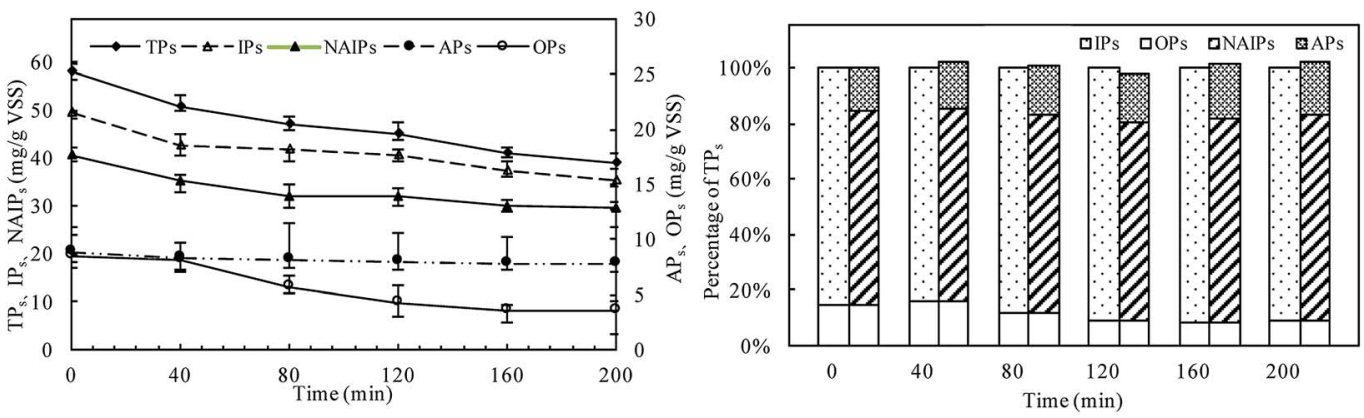

(b) $15^{\circ} \mathrm{C}$

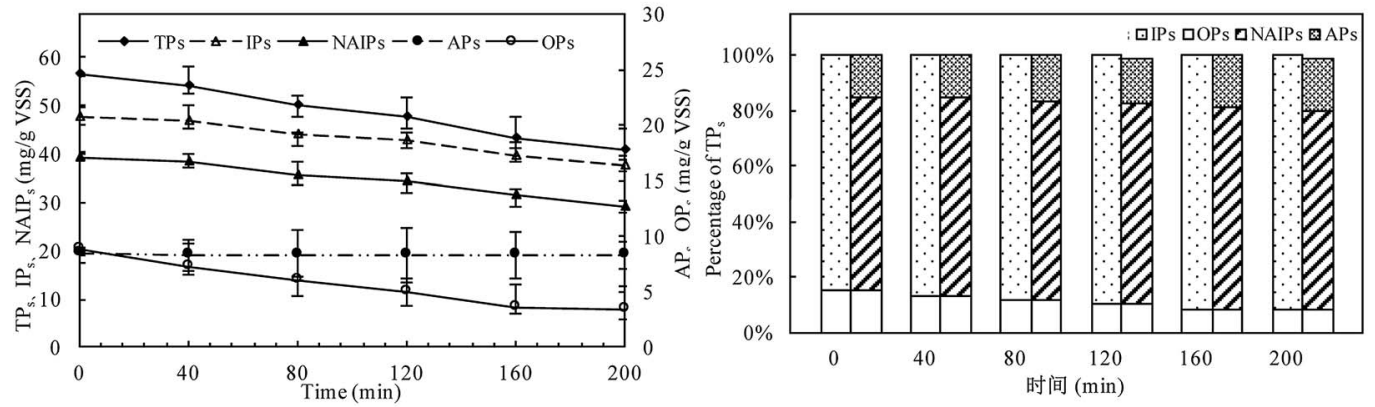

(c) $25^{\circ} \mathrm{C}$
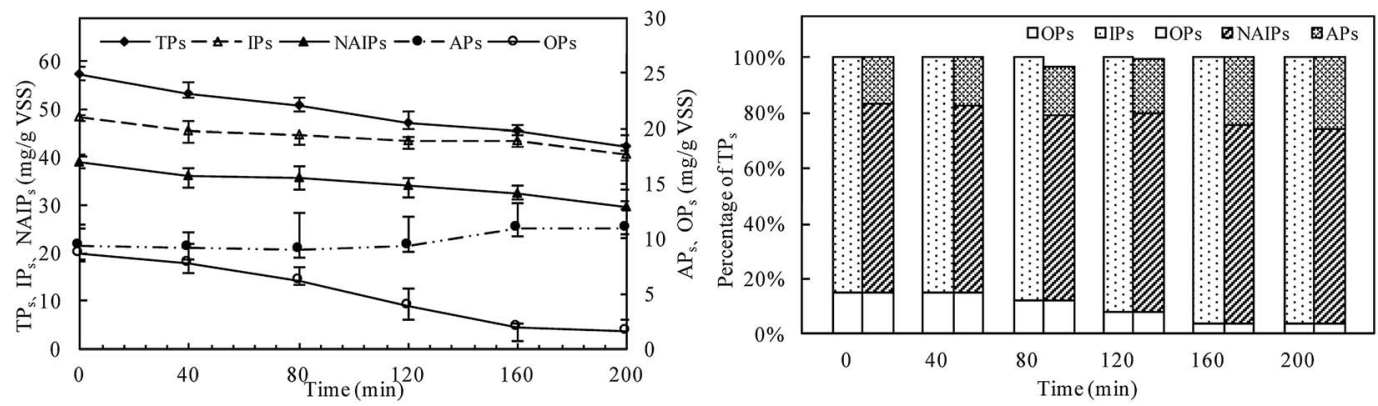

(d) $35^{\circ} \mathrm{C}$

Fig. 4 Changes of phosphorus fractions in the sludge phase at different temperatures.

its precipitates in biological phosphorus accumulation were dominant in EPS. Such results were similar with the observation of Cloete and Oosthuizen, who found that phosphate precipitation was absorbed by EPS in the WWTPs. ${ }^{23}$

\subsection{Intracellular phosphorus contents}

Temperature is the key parameter affecting the microbial population and organic components during the anaerobic phosphorus release process, as shown in Table 2 and Fig. $\mathrm{S} 1 . \dagger$ The concentrations of the soluble ortho- $\mathrm{P}\left(\mathrm{PO}_{4}{ }^{3-}-\mathrm{P}\right)$ and acetate 

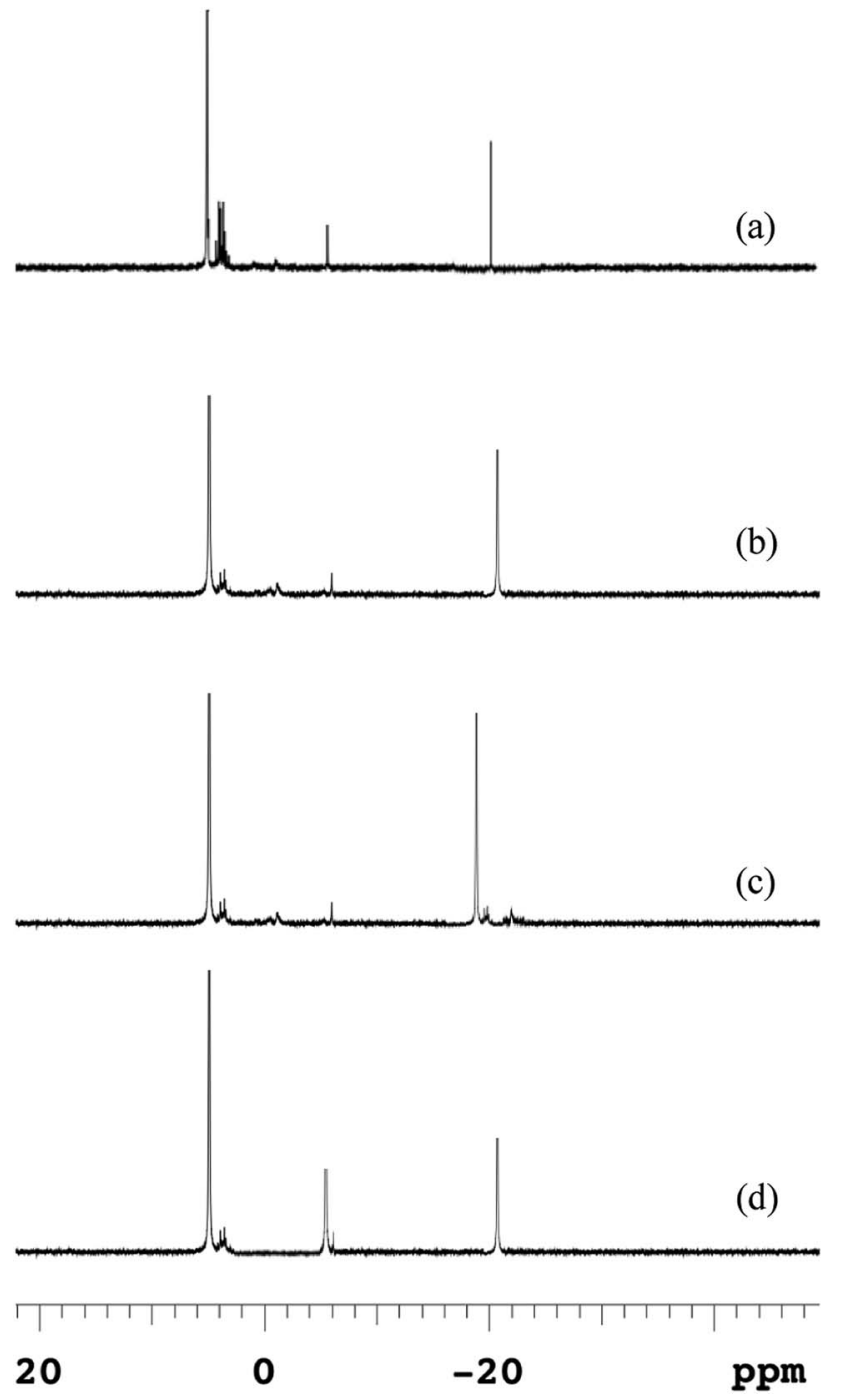

Fig. 5 Changes of ${ }^{31} \mathrm{P}$-NMR spectra of EPS in anaerobic sludge at different temperatures (a) $5{ }^{\circ} \mathrm{C}$; (b) $15^{\circ} \mathrm{C}$; (c) $25^{\circ} \mathrm{C}$; (d) $35^{\circ} \mathrm{C}$.

during the anaerobic release process were consistent with the expected enriched PAOs. A large amount of organic P and polyphosphates was accumulated in the microbial cellular materials, and the intracellular release process could be realized a conversion from NRP to SRP fraction by PAOs.

The metabolism of PAOs was dependent on the internal stored carbon compound and energy source. The glycogen concentration at the first 10 min was not decreased obviously with an obvious increase of phosphorus concentration in the liquid phase, which verified that poly-P in microbial cells may be used as the prior energy for the anaerobic $P$ release with the long-chain poly-P degraded to short-chain poly-P or ortho-P. The intracellular poly-P storage at $15{ }^{\circ} \mathrm{C}$ was the least while the hydrolysis of intracellular poly-P was limited when temperature increased, indicating that the microbial population of anaerobic sludge with a lower intracellular P-content at other temperatures might consist of species other than PAOs (i.e., GAOs). The presence of GAOs might interfere with the accumulation of poly-P by PAOs. ${ }^{11}$
The PHA compounds contained PHB and PHV, and their values increased with the release proceeding. The increased PHA content accelerated the disintegration and the following cell lysis of anaerobic sludge. Moreover, more PHV formed in the later period of anaerobic treatments especially at higher temperatures due to more glycogen degradation. ${ }^{44}$ This phenomenon could be explained by the reason that the glycogen pathways gradually replaced the poly-P pathways for $\mathrm{P}$ release.

The higher $\mathrm{PHA}_{\text {synthesized }} / \mathrm{HAc}_{\text {uptake }}$ ratio occurred at $35{ }^{\circ} \mathrm{C}$, but a higher P-release did not occur under this temperature condition. The ratio of $\mathrm{P}_{\text {release }} / \mathrm{HAc}_{\text {uptake }}$ reduced from $0.75 \mathrm{P}$ $\mathrm{mol} / \mathrm{C}-\mathrm{mol}\left(15^{\circ} \mathrm{C}\right)$ to $0.22 \mathrm{P}-\mathrm{mol} / \mathrm{C}-\mathrm{mol}\left(35^{\circ} \mathrm{C}\right)$, indicating the metabolic pathway of PAOs shifted polyphosphateaccumulating metabolism (PAM) to glycogen-accumulating metabolism (GAM) when the temperature increased from $15{ }^{\circ} \mathrm{C}$. And the ratio of Glycogen degraded $/ \mathrm{HAc}_{\text {uptake was in a range }}$ of 0.31-0.50 C-mol/C-mol for the PAO-enriched cultures, while 0.92-1.25 C-mol/C-mol for the GAO-enriched cultures, the stoichiometric ratio of Glycogen degraded $/ \mathrm{HAc}_{\text {uptake }}$ in this study indicated that the metabolic pathway of PAOs was shifted to GAM at higher temperatures $\left(25^{\circ} \mathrm{C}\right.$ and $\left.35^{\circ} \mathrm{C}\right) .{ }^{45}$ The similar results have been reported by Mulkerrins et al. ${ }^{46}$ Thus, the microbial population dynamics showed a shift from the dominance of PAOs to GAOs with the increase of temperature. Notably, the phosphorus concentration in the bulk solution was much lower than that at other temperatures, while the release content of $\mathrm{TP}_{\mathrm{EPS}}$ at $35{ }^{\circ} \mathrm{C}$ was largest. This was verified that $\mathrm{P}$ release processes between extracellular and intercellular substances were independent. Because the intracellular poly-P was limited at $35{ }^{\circ} \mathrm{C}$, the glycogen utilization might be gradually replaced by the tricarboxylic acid (TCA). PAOs could tune their metabolic pathway between the dominance of PAM and GAM along with the change of intracellular available poly-P level. ${ }^{47}$

Although the content of active biomass was highest at $5{ }^{\circ} \mathrm{C}$ (MLVSS content $=2240 \mathrm{mg} \mathrm{L}^{-1}$ ), the intracellular poly-P content was higher than that at $15{ }^{\circ} \mathrm{C}$. This was because the activity of exopolyphosphatases was weakened at the relatively low temperature, and hence some short-chain poly-P could not be degraded into ortho-P. As a result, they could be stored in the EPS matrix and not participated in the following $\mathrm{P}$ release. That's why the concentration of $\mathrm{TP}_{\mathrm{EPS}}$ at $5{ }^{\circ} \mathrm{C}$ after $200 \mathrm{~min}$ anaerobic $\mathrm{P}$ release was increased.

\subsection{Relationship between intracellular and extracellular $\mathbf{P}$ release/transfer}

The $\mathrm{P}$ release ability of anaerobic sludge was dependent on both intracellular and extracellular $\mathrm{P}$ release processes. The $\mathrm{P}$ release processes in intracellular and extracellular phases were relational and relatively independent with each other. Temperature could not only change the release of different $\mathrm{P}$ fractions in the sludge phase, but also change the mechanisms of PAOs and EPS reaction process.

Based on the above results, a possible organically-bound Prelease pathway of anaerobic sludge at different temperatures 
Table 2 Biomass composition of anaerobic sludge at different temperatures ${ }^{a}$

\begin{tabular}{|c|c|c|c|c|}
\hline Parameter & $5^{\circ} \mathrm{C}$ & $15^{\circ} \mathrm{C}$ & $25{ }^{\circ} \mathrm{C}$ & $35^{\circ} \mathrm{C}$ \\
\hline MLSS (mg L $\left.{ }^{-1}\right)$ & 2500 & 2320 & 2420 & 2030 \\
\hline $\operatorname{MLVSS}\left(\mathrm{mg} \mathrm{L}^{-1}\right)$ & 2240 & 2130 & 1870 & 1680 \\
\hline Active biomass $\left(\mathrm{mg} \mathrm{L}^{-1}\right)$ & 1896.71 & 1768.05 & 1509.54 & 1415.31 \\
\hline $\mathrm{P}_{\text {release }} / \mathrm{HAc}_{\text {uptake }}(\mathrm{P}-\mathrm{mol} / \mathrm{C}-\mathrm{mol})$ & 0.68 & 0.75 & 0.53 & 0.22 \\
\hline Glycogen $_{\text {degraded }} / \mathrm{HAc}_{\text {uptake }}(\mathrm{C}-\mathrm{mol} / \mathrm{C}-\mathrm{mol})$ & 0.50 & 0.49 & 0.99 & 1.03 \\
\hline
\end{tabular}

was proposed to enhance P-release with the increase of $\mathrm{TP}_{\mathrm{L}}$ concentration in the bulk solution. Firstly, EPS not only transported ortho-P into the bulk solution, but also stored $\mathrm{P}$ (shortchain poly-P and ortho-P) in EPS. Long et al. also verified that EPS played an important role in transfer and transformation of ortho-P during the anaerobic P release. ${ }^{25}$ Due to the high biosorption ability, the more proportion of extracellular phosphate minerals was accumulated in EPS at a low temperature $\left(2.18 \mathrm{mg} \mathrm{g}_{\mathrm{vss}}{ }^{-1}\right.$ at $\left.5^{\circ} \mathrm{C}\right)$. Secondly, PAOs were found to changing their metabolic pathways from PAM to GAM with the increase of temperature. PAOs in the anaerobic sludge could preferentially utilize the energy from the degradation of intracellular poly-P (especially long-chain poly-P) for metabolic activity for $\mathrm{P}$ release. The autolysis of microbial cells was the driving force for the release of intracellular poly-P. The hydrolysis of poly-P led to the final release of ortho-P. ${ }^{49,50} \mathrm{Li}$ et al. verified that the highest PAOs activity was obtained at a moderate temperature. ${ }^{51}$ But the mass transfer between microbial cells and EPS was not benefited by $5{ }^{\circ} \mathrm{C}$ because bacteria in microbial aggregates was protected by more content of EPS in "uncomfortable" environment for survival. Therefore, intracellular $\mathrm{P}$ dynamic played a decisive role for the anaerobic $\mathrm{P}$ release at different temperatures.

\section{Conclusions}

The study investigated the effect of temperature varied from $5{ }^{\circ} \mathrm{C}$ to $35{ }^{\circ} \mathrm{C}$ on the anaerobic $\mathrm{P}$ release. The interactions between the role of EPS and the PAOs metabolic pathway for the conversation from NRP to RP fraction and the anaerobic $\mathrm{P}$ release were considered. The main conclusions are summarized as follows:

(1) The intracellular biochemical metabolism and EPSassociated $\mathrm{P}$ reactions, i.e., hydrolysis and adsorption processes, were relatively independent. In this study, $15^{\circ} \mathrm{C}$ was the optimal temperature for the conversion from NRP to RP fraction in the sludge phase due to the highest $\mathrm{TP}_{\mathrm{L}}$ concentration observed.

(2) A higher temperature could effectively improve the $P$ bioavailability resulting from the conversion of $\mathrm{NAIP}_{\mathrm{s}}$ to $\mathrm{AP}_{\mathrm{S}}$. The ratio of potential bio-available phosphorus to $\mathrm{TP}_{\mathrm{s}} \mathrm{kept}$ almost constant (78.01-82.24\%), because of a high potential bio-available phosphorus stored in the anaerobic sludge.
(3) Poly-P and ortho-P were the dominant forms of P in EPS. A higher temperature enhanced the hydrolysis of EPS, which reduced the macromolecules and particulate matter into the metabolizable low-molecular-weight P.

(4) P stored in EPS and transported by EPS were closely related to the PAOs activity and the intracellular $\mathrm{P}$ dynamic metabolism played a decisive role for $\mathrm{P}$ release.

\section{Conflicts of interest}

There are no conflicts to declare.

\section{Acknowledgements}

The authors gratefully acknowledge funding from Project 51121062 (National Creative Research Groups) supported by National Nature Science Foundation of China.

\section{References}

1 J. Cooper, R. Lombardi, D. Boardman and C. CarliellMarquet, Resour., Conserv. Recycl., 2011, 57, 78-86.

2 S. Yang, W. Guo, Y. Chen, X. Zhou, H. Zheng, X. Feng, R. Yin and N. Ren, RSC Adv., 2014, 4, 52892-52897.

3 Y. Xu, H. Hu, J. Liu, J. Luo, G. Qian and A. Wang, Chem. Eng. J., 2015, 267, 260-265.

4 C. Xie, J. Zhao, J. Tang, J. Xu, X. Lin and X. Xu, Bioresour. Technol., 2011, 102, 2455-2461.

5 M. Kacprzak, E. Neczaj, K. Fijałkowski, A. Grobelak, A. Grosse, M. Worwag, A. Rorat, H. Brattebo, A. Almås and B. R. Singh, Environ. Res., 2017, 156, 39-46.

6 X. Zheng, Y. Su, Y. Chen, Y. Wei, M. Li and H. Huang, RSC Adv., 2014, 4, 45953-45959.

7 F. Zeng, Q. Zhao, W. Jin, Y. Liu, K. Wang and D. Lee, Chem. Eng. J., 2018, 344, 254-261.

8 K. Venkiteshwaran, P. J. McNamara and B. K. Mayer, Sci. Total Environ., 2018, 644, 661-674.

9 American Public Health Association (APHA), Standard methods for the examination of water and wastewater, American Public Health Association. Washington D.C, 2012.

10 J. J. G. Medeiros, B. Pérez Cid and E. Fernández Gómez, Anal. Bioanal. Chem., 2005, 381, 873-878. 
11 Y. Zhang, M. S. Islam, K. N. McPhedran, S. Dong, E. M. Rashed, M. M. Shafer, A. M. Noureldin and M. G. ElDin, $R S C$ Adv. , 2017, 7, 45938-45948.

12 S. Yang and X. Li, Process Biochem., 2009, 44, 91-96.

13 H. L. Zhang, G. P. Sheng, W. Fang, Y. P. Wang, C. Y. Fang, L. M. Shao and H. Q. Yu, Water Res., 2015, 84, 171-180.

14 R. P. X. Hesselmann, R. Von Rummell, S. M. Resnick, R. Hany and A. J. B. Zehnder, Water Res., 2000, 34, 34873494.

15 T. T. Qian and H. Jiang, ACS Sustainable Chem. Eng., 2014, 2, 1411-1419.

16 J. Zou and Y. Li, Bioresour. Technol., 2016, 218, 18-26.

17 Z. W. He, W. Z. Liu, L. Wang, C. C. Tang, Z. C. Guo, C. X. Yang and A. J. Wang, Bioresour. Technol., 2016, 222, 217-225.

18 S. Wacławek, K. Grübel, P. Dennis, V. T. P. Vinod and M. Černík, Chem. Eng. J., 2016, 291, 192-198.

19 N. Sayi-Ucar, M. Sarioglu, G. Insel, E. U. Cokgor, D. Orhon and M. C. M. van Loosdrecht, Water Res., 2015, 84, 8-17.

20 Y. Shi, J. Huang, G. Zeng, Y. Gu, Y. Chen, Y. Hu, J. Zhou, Y. Yang and L. Shi, Chemosphere, 2017, 180, 396-411.

21 W. Zhang, S. Peng, P. Xiao, J. He, P. Yang, S. Xu and D. Wang, RSC Adv., 2015, 5, 1282-1294.

22 Y. Ding, Y. Tian, Z. Li, W. Zuo and J. Zhang, Bioresour. Technol., 2015, 192, 105-114.

23 T. E. Cloete and D. J. Oosthuizen, Water Res., 2001, 35, 35953598.

24 H. C. Flemming and J. Wingender, Nat. Rev. Microbiol., 2010, 8, 623.

25 X. Long, R. Tang, Z. Fang, C. Xie, Y. Li and G. Xian, Chemosphere, 2017, 189, 679-688.

26 W. Huang, W. Cai, H. Huang, Z. Lei, Z. Zhang, J. Tay and D. Lee, Water Res., 2015, 68, 423-431.

27 S. Yu, P. Sun, W. Zheng, L. Chen, X. Zheng, J. Han and T. Yan, Bioresour. Technol., 2014, 171, 80-87.

28 W. Zhang, B. Cao, D. Wang, T. Ma and D. Yu, Biochem. Eng. J., 2016, 106, 37-47.

29 W. Li, H. Zhang, G. Sheng and H. Yu, Water Res., 2015, 86, 85-95.

30 H. Liu and H. H. P. Fang, J. Biotechnol., 2002, 95, 249-256.

31 B. L. Turner, N. Mahieu and L. M. Condron, Soil Sci. Soc. Am. J., 2003, 67, 497-510.

32 J. Ahlgren, L. Tranvik, A. Gogoll, M. Waldebäck, K. Markides and E. Rydin, Environ. Sci. Technol., 2005, 39, 867-872.
33 Y. Khambhaty, K. Mody, S. Basha and B. Jha, Chem. Eng. J., 2009, 145, 489-495.

34 A. Rahmani-Sani, A. Hosseini-Bandegharaei, S. Hosseini, K. Kharghani, H. Zarei and A. Rastegar, J. Hazard. Mater., 2015, 286, 152-163.

35 Y. Wang, J. Geng, Z. Ren, W. He, M. Xing, M. Wu and S. Chen, Bioresour. Technol., 2011, 102, 5674-5684.

36 B. Frølund, T. Griebe and P. H. Nielsen, Appl. Microbiol. Biotechnol., 1995, 43, 755-761.

37 S. Y. Lee, Trends Biotechnol., 1996, 14, 431-438.

38 Y. N. Liu, S. Yu, G. Xue and F. B. Zhao, Water Sci. Technol., 2006, 54, 257-265.

39 X. M. Liu, G. P. Sheng, H. W. Luo, F. Zhang, S. J. Yuan, J. Xu, R. J. Zeng, J. G. Wu and H. Q. Yu, Environ. Sci. Technol., 2010, 44, 4355-4360.

40 H. L. Zhang, G. P. Sheng, W. Fang, Y. P. Wang, C. Y. Fang, L. M. Shao and H. Q. Yu, Water Res., 2015, 84, 171-180.

41 X. Zheng, P. Sun, J. Han, Y. Song, Z. Hu, H. Fan and S. Lv, Process Biochem., 2014, 49, 2207-2213.

42 W. Huang, W. Huang, H. Li, Z. Lei, Z. Zhang, J. H. Tay and D. J. Lee, Bioresour. Technol., 2015, 193, 549-552.

43 L. P. Lichko, T. V. Kulakovskaya and I. S. Kulaev, Process Biochem., 2002, 37, 799-803.

44 D. Wu, G. A. Ekama, H. G. Wang, L. Wei, H. Lu, H. K. Chui, W. T. Liu, D. Brdjanovic, M. C. van Loosdrecht and G. H. Chen, Water Res., 2014, 49, 251-264.

45 Y. Zhou, M. Pijuan, R. J. Zeng, H. Lu and Z. Yuan, Water Res., 2008, 42, 2361-2368.

46 D. Mulkerrins, A. D. W. Dobson and E. Colleran, Environ. Int., 2004, 30, 249-259.

47 B. Acevedo, A. Oehmen, G. Carvalho, A. Seco, L. Borrás and R. Barat, Water Res., 2012, 46, 1889-1900.

48 D. Brdjanovic, S. Logemann, M. C. M. van Loosdrecht, C. M. Hooijmans, G. J. Alaerts and J. J. Heijnen, Water Res., 1998, 32, 1035-1048.

49 H. L. Zhang, W. Fang, Y. P. Wang, G. P. Sheng, R. J. Zeng, W. W. Li and H. Q. Yu, Environ. Sci. Technol., 2013, 47, 11482-11489.

50 A. Kuroda, N. Takiguchi, T. Gotanda, K. Nomura, J. Kato, T. Ikeda and H. Ohtake, Biotechnol. Bioeng., 2002, 78, 333338.

51 N. Li, N. Q. Ren, X. H. Wang and H. Kang, Bioresour. Technol., 2010, 101, 6265-6268. 